\title{
OPENBARING, TEOLOGIE EN DIE REGSWETENSKAP
}

In die jongste tyd is telkens en weer gewaarsku teen die gevare van oorspesialisasie en die hipertrofie van professionalisme.' Die gemis aan 'n totaliteitsvisie wat hiermee gepaard gaan, word dan ook tereg teengegaan en wel deur aan die Wysbegeerte as die Wetenskap van die totaliteit van die kosmos in toenemende mate sy regmatige plek as wetenskapsintegreerder te gun. Hierdie grootmoedige gun van 'n plek in die son van geleerdheid kan egter ook uit bedenklike motiewe plaasvind. Die vakwetenskaplike kan nie of wil nie die plek en betekenis van sy spesifieke vak bepaal en bepeins nie en vind dit in elk geval moeilik om die verband tussen Gods Woord en sy besondere vak in duidelike perspektief te sien; vandaar dan 'n grootmoedige toelaat dat die wysbegeerte die "veritas" dien terwyl die eie ek tevrede is om die „utilitas” onderdanig te wees. Dit is werklik nie 'n denkbeeldige gevaar dat die student wat hom koester in die warmte van 'n totaliteitswetenskap uiteindelik bewende van kouekoors gelaat word, omdat hy ook blootgestel word aan die ysige koue van vakwetenskaplike inkerkering waar die lig van Gods Woord skynbaar glad nie of te weinig mee te spreek het. Indien ons waarlik 'n inrigting vir Christelike Hoër Onderwys wil wees, help dit nie om ons beginsels in goudborduursel op 'n pragtige vaandel te plaas nie, terwyl tog die een wat die vaandelstok omhoog hou eintlik nie weet wat die inhoud van die vaandelspreuk is nie. Ook die vakwetenskaplike sal gedwing moet word om gehoor te gee aan die stem wat in stygende crescendo van 'n vragende "is dit ons erns?" aanrol deur 'n ,laat dit ons erns wees" tot 'n magtige "nou is dit ons erns".

In hierdie eeufeesjaar is dit ' $n$ gepaste tyd om te besin oor die vraag of dit genoegsaam is om die "Sola Scriptura" by uitstek te proklameer in en oor die wetenskaplike rigtinge waar die skrifbeginsels haas selfevident is, en die student wat hom wens te bekwaam in meer professionele rigting in die woestyn te laat, waar hy alleen 'n stofverwaaide spoor kan volg wat vir hom in elk geval al spoedig verdwyn in 'n newel van abstraksies te groot om werklik duidelik en helder deur te sien. 'n Eeu van „Strijd en Zegen” kan maklik gevolg word deur 'n „eeu van onreg”, indien die afstand tussen grootsheid van totaliteitsvisie en die engheid van spesialisasie nie deur die 
spesialis self oorbrug word nie.

U mag dink dat ek my onnodig besorgd maak en van 'n molshoop 'n yslike gebergte skilder. Dit is egter 'n feit dat talle studente wat hul opleiding aan hierdie inrigting gehad het in later jare moes beken dat hul nie weet hoe die Christelike beginsels in die praktiese beoefening van hul besondere beroepsrigting te pas kom nie, en soms nog erger, dat hul die besondere vakrigting maar net sowel aan 'n neutrale universiteit kon gaan bestudeer het. Die uitdrukking "Christelike onderwys" het 'n modekreet geword, en net soos J. D. du Toit dit 'n halfeeu gelede nodig gevind het om 'n vraagteken te plaas by die mode om die woord "Calvinisme" te maklik te verbind aan ons volksaard, ${ }^{2}$ net so kan dit tyd word om die "Christelike" as adjektief by „onderwys" 'n slag onder die vergrootglas te neem. Die geleentheid wat ons gebied word om in hierdie reeks fakulteitsgewys te besin oor die verband tussen Gods geopenbaarde Woord en die verskillende wetenskappe moet dan ook verwelkom word, maar dit verdien aanbeveling dat die tema onder bespreking ook by 'n geskikte geleentheid betrek word by besondere vakke of vakgroepe binne 'n bepaalde fakulteit. Met dankbaarheid moet vermeld word die lofwaardige werk wat reeds deur verskillende liggame in die verband gedoen is, maar dit verminder nie die onus wat op elke wetenskaplike rus om wat sy eie vak betref, in U lig die lig te sien nie.

Hierdie lesing handel oor die openbaring en die regswetenskap, „een weidse titel voor een korte beschouwing door een leek op theologisch gebied" soos 'n Nederlandse juris dit genoem het. ${ }^{3}$ In een lesing kan nóg 'n oorsig verkry word oor die Godsopenbaring in sy oorstelpende rykdom in die Skrif en in die ondeurgrondelike wondere van die natuur nóg oor die reg as 'n samebundeling van wetenskappe ${ }^{4}$ wat net soseer van mekaar verskil as die kleure wat deur die prisma gesplits word, selfs al beperk ons ons slegs tot die samehang tussen Skrif en reg.

Wat die begrip „openbaring” betref is dit sekerlik nie sonder belang nie dat juis die boek in die Bybel wat hierdie naam dra, selfs vir die eksegeet 'n openbaring van onbegryplike duisterhede inhou, en dat die openbaring wat in Genesis volg op die woorde „In die begin het God die hemel en die aarde 
geskape", steeds weer en weer die penne in beroering bring, omdat hierdie openbaring vir ons deur die sonde verduisterde verstand soms meer lyk op 'n kleed wat diepe geheimenisse verberg. Inderdaad moet ons by die aanvaarding dat Gods Woord die Waarheid is, ook erken dat wat daardie Waarheid is, of liewer wat die inhoud van daardie Waarheid is, in vele opsigte soos die goud in die kors van die aarde latent bly, maar vatbaar vir ontginning - 'n ontginning wat vanweë menslike gebreke steeds sal bly 'n ,,sien deur 'n spieël in 'n raaisel". Kennis van Gods Woord is vir enige Christelike wetenskaplike onontbeerlik, maar om daardie kennis tien maal te bekom en elke keer verkeerd te bekom kan meer gevaar as heil inhou. Self is die non-teoloog nie geroepe om te teologiseer nie en daarom het die teoloog die besondere taak om nie alleen Gods Woord diep, grondig en wetenskaplik te bestudeer nie maar ook om wetenskaplikes op ander as die teologiese erf behulpsaam te wees in die skugtere ontvouing van die Cognitio ectypa Dei. Die „Lehnsătze” wat die Teologie aan die ander fakulteite verskaf en moet verskaf, bring mee dat die Opera Omnia van 'n Calvyn, 'n Kuyper, 'n Bavinck en andere ook 'n plek het op die boekrak van skeikundige, bioloog, ekonoom, sosioloog en juris. Met dankbaarheid dink ons hier bv. aan die magistrale wyse waarop Kuyper in sy "De Gemeene Gratie" die regverdiging van die doodstraf uiteensit," 'n onderwerp waarop ons later uitvoeriger terugkom. ${ }^{6}$

Dat ons Gods Woord moet laat meespreek ook in ons wetenskaplike besig wees, val nie te betwyfel nie, maar die hóé ons dit doen is nie altyd met soveel sekerheid te bepaal nie. In feitlik alle wetenskaplike geskrifte wat die lig uit die Skrifopenbaring put, kom die stelling voor dat die Bybel geen wetenskaplike handboek is nie. Dit is noodsaaklik om dit voorop te stel, maar die poneer van hierdie stelling is geen waarborg vir die korrekte gebruik van die Bybelwaarhede nie. Trouens, die ongelowige sal ook maar té grif gryp na die argument dat die Bybel geen wetenskaplike handboek is nie, om dan geen verdere notisie daarvan te neem nie. Doen ons dit, helaas, nie soms ook nie? Verder, die Fabels van Aesopus en die werke van 'n Shakespeare, 'n Dante en 'n Goethe is tog ook geen wetenskaplike handboeke nie, maar niemand sal tog die didaktiese waarde ontken van die Aesopus-verhaal dat 'n "Wolf, wolf". geskree gevaarlik is nie. Niemand sal dit vreemd vind dat in 
'n wetenskaplike geskrif aangehaal word die pragtige lofsang oor die vrugte van genade wat 'n Portia teenoor Shylock besig nie, soos gebeur het in 'n artikel onder die titel „La retribution penale".? Word die Bybel nie soms op hierdie wyse verlaag tot 'n boek i.p.v. dié Boek nie? Handige en waardevolle tekste word tog, (soms heeltemal onwetend) selfs deur geheel en al ongelowiges aangehaal, en uit die Skrif self weet ons dat die Satan self nie onvertroud met tekskennis is nie en dit ook met sataniese lis en behendigheid kan gebruik. Aan die ander kant is daar diegene wat in alle opregtheid Gods Woord die uitgangspunt van hul wetenskaplike denke wil maak maar die leser tog laat met die onbehaaglike gevoel dat die selfuitgesponne, hoewel goed gesistematiseerde eie konstruksie verhef word tot ' $n$ evangelie in eie reg, waarvan niemand durf verskil nie. Prof. V. Hepp het byna vier decennia gelede 'n behartenswaardige woord laat val wat ons mutatis mutandis vandag nog ons eie kan maak. Ek haal sy woorde betreklik volledig aan om dan ' $n$ eie toepassing in ' $n$ ander verband te gee - 'n toepassing wat ek geredelik toegee eintlik buite my wetenskaplike terrein val maar wat ek tog in beskeidenheid wil uiter, sy dit dan moontlik meer geïnspireer deur gevoel as verstand. Hepp laat hom soos volg uit:

„Ik zal hier de tegenwoordige richtingen op theologisch gebied beoordeelen naar haar dogmatische strekking. Dicht mij op grond daarvan niet toe, dat, wijl ik dogmatiek en aanverwante vakken doceer, ik deze in blinde voorliefde voor den wortel en de kroon der theologie houd. Geloof mij, dat zulk dogmatisch imperialisme mij ten eenenmale vreemd is. De exegetische en kerkelijke vakken vat ik op als gecoördineerd met de dogmatische. Zoo verzet ik mij... ten sterkste tegen dogmatische exegese, waaraan vele dogmatici zich maar al te zeer hebben bezondigd. De dogmatiek zou zich aan machtsoverschrijding schuldlg maken, indien zij aan de wetenschappelijke uitlegging zou willen voorschrijven, hoe zij bepaalde teksten der heilige Schrift heeft te interpreteeren. Integendeel past het de dogmatiek te luisteren naar wat de exegese na nauwgezet onderzoek als haar eindconclusie uitspreekt... De dogmatische disciplinae zijn... in hooge mate van de andere afhanklijk.

Doch omgekeerd kunnen ook die andere zich niet recht ontplooien zonder de dogmatiek. Er bestaan tusschen alle vak- 
groepen der theologie een relatie van wederkeerige afhanklijkheid. Neem de kwestie wat is het wezen van de Heilige Schrift? Mag men als eisch stellen, dat eerst heel de Bijbel tekst voor tekst wetenschappelijk moet zijn verklaard, voor en aleer men het wezen van de Schrift kon grijpen? Immers neen. Het wezen der Schrift stond voor den geloovige, die in allen eenvoud zijn Bijbel las, reeds vast eer de wetenschappelijke uitlegging was geboren. Dat de Schrift het onfeilbaar Woord van God is, ... werd niet aanvaard als resultaat van exegese. Het behoorde tot den inhoud van het voor-wetenschappelijke geloof. En nu maakte de dogmatiek dien inhoud tot object van systematische reflexie en reproductie. Ook de exegese moet tot de Schrift komen met het dogma van haar onfeilbaarheid... Zal de exegese èn christelijk èn wetenschappelijk zijn, dan moet zij zich over het wezen der schrift laten voorlichten door de dogmatiek". ${ }^{8}$

Hierdie pragtige gebalanseerde houding wil ek voorhou as voorbeeld vir wat die verhouding tussen Teologie, Wysbegeerte en die vakwetenskappe behoort te wees. Die idee dat die Teologie die regina scientiarum is, is in Calvinistiese kringe reeds grondiglik gekritiseer en afgewys. Tereg ook! Maar dit kom my tog voor dat die bepaling van die presiese plek en taak van die Teologie die geleerdes in 'n dilemma beland het. Wanneer ' $n$ bepaalde wysgerige sisteem, wat die plek van die Teologie betref, tot 'n konklusie kom wat op sy minste kwestieus is, dien met erns gevra te word of onverklaarbare misteries nie met menslik logiese spitsvondighede in 'n keurslyf met baleine en al gedwing word nie - en verder of die "logies"uitgewerkte sisteem nie êrens aan 'n „ommissus” mank gaan nie, tot so ' $n$ mate dat die eie sisteem in die weg staan van te aanvaar wat eeue as die hart van die Teologie beskou is nie. Met my laaste opmerking bedoel ek geensins om die pleit vir represtinasie op te neem nie. Die reeds angehaalde Hepp het kort en bondig maar seer tereg gesê: ,Zonder een onderzoek naar het vaderschap in te stellen, mag worden aangenomen dat de repristinatie de gemakzucht tot moeder heeft". 9 Daar moet egter gewaak word om nie die kennis van die Skrif soos mede-verwerf deur die wetenskaplike arbeid van Teoloë aan te sien vir kennis wat maar self verwerf kon word nie. So 'n houding herinner aan iemand wat die solderdeur bereik het en nou die leer onder hom uitskop as 'n toekomstige onnodigheid. ${ }^{10}$ 
'n Goed geharmoniseerde beskouing meen ons aan te tref by Stoker in sy reeds bekend geworde „Beginsels en Metodes in die Wetenskap"." Nòg Teologie, nòg Wysbegeerte, nòg Vakwetenskap mag imperialisties die een die ander 'n plek ontsê of die een die ander ' $n$ etiket om die nek hang bloot omdat woordgebruik en terminologie soms verskil. Om die een die ander diensbaar te wil wees is lofwaardig, maar dan geen roeme in die diensbaarheid nie, want dit is ' $n$ contradictio in terminis net soveer as ' $n$ gespog met eie beskeidenheid dit is. Laat ons verder dan die een die ander ontvang as dona dativa en besef dat ons interafhanklik is ook al handhaaf elk onverswak sy soewereiniteit in eie kring.

$\mathrm{U}$ mag vra waarom ek as juris my bekommer oor die objek van die teologie. Immers die grote A. Kuyper het reeds gesê: „Ook al bleek dus dat er in het organisme der wetenschap geen plaats voor de Theologie was, dit zou haar op zichzelf noch in het minst niet declineeren, gelijk ze omgekeerd niet hel minst in waarde klimt, zoo het blijkt, dat ze metterdaad onder de wetenschappen is te rangschikken". ${ }^{12}$ Tog kan ek my nie vereenselwig met 'n beskouing wat in feite daarop neerkom dat elkeen vir sy vakgebied met ewe veel (of is dit ewe min) gesag uit die Skrif kan put nie. Die probleem verbonde aan presies in een taal te sê wat in 'n ander uitgedruk is, noodsaak alreeds die onontbeerlike hulp van die eksegeet. 'n Goeie voorbeeld hiervan vind $u$ in Johannes $14: 6$, ,Ek is die weg en die waarheid en die lewe" - in Grieks is die be. paalde lidwoord bekend, in Latyn nie. Hoe kan hierdie teks wat in Afrikaans wel tot sy reg kom in Latyn tot sy reg kom? Die bekende Vulgata bevat die niksseggende en ongekwalifiseerde „via, veritas, vita”, die vertaling van Beza verhelp die onduidelike segging deur ,illa" voor elk van die drie woorde in te voeg - 'n oplossing wat miskien weer by gemis aan 'n gepaste lidwoord té sterk kwalifiseer. Al is dit waar dat "nòch aan de Theologie, nòch aan enige ander wetenschap het recht toekomt te gaan instaan tussen de gelovige en de goddelijke Woordopenbaring, waarmee hij in zijn hart gebonden is...") en al sou ons ten volle die stelling onderskryf: „Jezus schreef nooit een 'Summa' als Thomas Aquinas, noch ooit een ,Kritik der reinen Vernunft' als Kant en toch klinkt nu nog zijn heilige naam ook in de kringen der naturalisten hoog boven den naam van alle deze coryphaeën der wetenschap uit"; 14 dan nog val 
die waarde van die skrifgebonde teologiese arbeid as ondersteunende illuminator nie te ontken nie. Die woord „skrifgebonde" moet hier beklemtoon word. 'n Aurelius Augustinus, 'n Johannes Calvyn en 'n Abraham Kuyper kon elkeen 'n verwoester van die geloof gewees het, miskien erger as Nietzsche, indien die geniale skerpsinnigheid van hierdie truimviri nie getemper was nie deur ' $n$ ingrype van die Heilige Gees, in die geval van Kuyper medebewerk deur die geloofsversekerde bemoeienis van 'n eenvoudige ou vroutjie. Skrifgebonde ook omdat in sekere sin alle kettery van teologiese herkoms is. ${ }^{15}$

Waar ek die verhouding Teologie-Regswetenskap wens te behandel, sien ek die Teologie as „die wetenskap wat tot voorwerp van ondersoek het, die kennis van God, wat deur die besondere openbaring, die Woord van God, tot ons gekom het" 16 of soos die meermaal genoemde Kuyper dit stel „... niet het ongekende Wezen Gods, maar de ons bekend gemaakte revelatio ectypa", "1 wat nie buite die kosmos lê nie, maar deur die openbaring juis in die kosmos gegee is. ${ }^{18}$ Dat daar 'n besondere verband tussen Teologie en Regswetenskappe moet wees, blyk duidelik uit die feit dat in die rangorde van gekompliseerdheid die juridiese wetskring of modaliteit van die pistiese wetskring slegs geskei word deur die sedelike. ${ }^{19}$ Sowel die Teologie as die Regswetenskappe behoort tot die normatiewe wetenskappe, d.w.s. elkeen stel die mens onder sekere behorenseise, verplig die mens tot die nakom van dit wat behoort nagevolg te word. Beide is as scientiae deur die noodwendige verduistering na die sondeval in aansyn geroep. Meer ooreenkomste en aanduidinge van affinitas of vicinitas sal stellig gevind kan word, maar alle naby-syn in die verband moet tog ook weer as relatief ingesien word. Om nader aan die Teologie te wees beteken nog nie dat die Regswetenskappe naby die Teologie is nie. Die studieveld van beide lê op verskillende terrein, en die opsetlike té naby bring aan mekaar kan sonder 'n geskikte katalisator selfs gevaarlik wees. So kan bv. nie van die regsgeleerde verwag word om as custos morum op te tree en plaasvervangend as 't ware die goddelike oordeel oor die innerlike konsensie uit te spreek nie. Die sondige denke van die mens is vir die regsgeleerde alleen in soverre betrek binne die veld van oordeel as wat die sondige denke vergestalt word in die uiterlike versteuring van die geordende verhouding tussen volk en volk, staat en individu, mens en mens en ook mens en juridiese objek. 
Dit wil egter geensins sê dat die reg nie 'n oordeel vel oor die afkeurenswaardige gesindheid van die mens nie. Trouens, begrippe soos opsetlik, nalatig, onagsaam, onverskillig, te kwaaie trou, bedrieglik, dieftig, verraderlik, meinedig en selfs liefdeloos is geen onbekendes binne die kader van die juridiese oordeelsapparaat nie, maar dan word hierdie uitwasse van die denke slegs beoordeel soos dit af te lei is uit die probatiewe waarde wat die handelwyse van die te oordele persoon daaraan gee. Die skuldbegrip in die reg, hoewel gebonde aan die handelwyse van die mens, vertoon desnietemin 'n verdiepingsproses wat ondergaan is in die sin dat die regsbegrip verruim is deur die inwerking van die regsidee. Om te ontwikkel het van 'n primitiewe „Erfolgshaftung" tot 'n moderne „Schuldhaftung" gebaseer op die beginsel "geen straf sonder skuld" meer bepaald in die strafreg, beteken dat die reg sy morele antisipasie gaan ontsluit het en daardeur ' $n$ verdieping van die sin van die reg ondergaan het. In die morele skuld wat 'n laakbare gebrek in die innerlike gesindheid van die dader onder die norm van die naasteliefde onthul, lê self weer 'n antisipasie op die skuld in die sin van die geloof besluit, wat op sy beurt uitwys na die openbaring van die sondeskuld teen God. ${ }^{20}$ Kort saamgevat beteken dit dat juridiese skuld binne die juridiese wel ' $n$ eie betekenis, sin of eiesoortigheid het, gedistansieer van skuld in morele of religieuse sin maar aan die ander kant tog ook dat die onlosmaaklike verband tussen misdadige of onregmatige skuld en uiteindelik die sondeskuld teen God as oorsaak van die menslike fale en beperktheid nie misgekyk kan word nie. In hierdie ontsluitings- of verdiepingsproses is dit vir my vanselfsprekend dat die Teologie ' $n$ besondere rol gespeel het, hoewel die Teologie uiteraard ook weer, histories gesien, soms ten goede soms ten kwade beïnvloed is deur verskillende geestesstrominge van die tydsgees. Tog bly dit waar dat die Teologie in sekere sin 'n leidende funksie vir die Regswetenskappe vervul, soos reeds aan die hand van die skuldbegrip verduidelik is. Hierdie afhanklik wees van die Regswetenskappe moet gedeeltelik ook verklaar word deur die feit dat die Regte nie maklik vooruit loop nie maar in sy ordeningstaak geleidelik aanpas uit vrees vir die verkragting van die regsekerheid, 'n element wat soms ten koste van reg. verdigheid beklemtoon word. Dit is werklik opvallend dat chronologies die teoloog Calvyn voor die juris Althusius kom 
en dat as teenpool van hierdie geleerdes Arminius voor Hugo de Groot die pleit opgeneem het vir die supremaat van menslike selfbeskikking. 'n Encyclopaedie van die Regsgeleerdheid deur 'n Herman Dooyeweerd of sy voorganger Willem Zevenbergen is nie in te dink sonder die baanbrekende ,Encyclopaedie der Heilige Godgeleerdheid" van 'n Kuyper nie.

Verhouding Teologie-Regswetenskap kan in meer as een betekenis opgevat word. Dit kan dui op die presiese plek wat elkeen in die konstellasie van wetenskappe inneem. Verhouding in hierdie sin verstaan, wens ek nie verder te bespreek nie nie omdat ek dit nie as belangrik beskou nie, maar ek dink ons kan aanvaar dat ondanks nuanse-verskille $u$ en ek dit wel in breë trekke eens sal wees oor hierdie onderwerp. Verhouding Teologie-Regswetenskappe wil ek liewer in Concreto neem, en omdat die Teologie in hierdie reeks sentraal figureer die vraag wat die Regswetenskappe aan die Teologie te danke het, aan die orde stel. Ek doen dit aan die hand van ' $n$ paar belangrike beginsels.

\section{Ordening en gesag}

In die geskiedenis van die mensheid het dit telkens gebeur dat daar 'n ondraaglike spanning ontstaan tussen owerheid en onderdaan. Sodra die despotisme van die staatsgesag met 'n beroep op sy inherente reg tot gesagsuitoefening die onderdaan laat voel dat sy regte vertree word, kom laasgenoemde in verset en soek na norme waaraan 'n groter geregheidsgehalte toegeken word. Die Romeine het by verjaging van Tarquinius Superbus die waarborg vir hul individuele vryheid gesoek in 'n verdeling van magte, in 'n tydsbeperking op die ampsduur en deur die verlening van ' $\mathrm{n}$ jus intercedendi aan die tribuni plebis. ' $\mathrm{n}$ Byna fanatieke weersin in alles wat na imperialisme neig, het 'n eienskap van die Romein gebly selfs tot in die eerste jare van die Prinsipaat. Die komplot teen Julius Caesar moet aan hierdie weersin gewyt word, en Augustus moes met versigtige trede en diplomatiese vernuf hierdie weersin oorwin voordat hy die eerste deurlugtige Imperator van die Romeinse keiserryk kon word. ${ }^{21}$ In die 5e eeu na Chr. en onder die invloed van die Christendom bemerk ons die eerste tekens dat die gesagspersoon hom van God afhanklik weet. Die Bisantynse keisers verkies nou om die titel divus imperator te laat vaar en bekend 
te staan as imperator Dei gratia vermoedelik op grond van 1 Korinthiërs 15: 10 „Maar deur die genade van God is ek wat ek is". As hierdie grasie Gods maar 'n diepe besef van kleinheid en geringheid voor God by die koninklike hoogwaar. dighede teweeg gebring het, sou die Franse revolusie-gees sekerlik nie so sterk geappelleer het op die menslike rede nie. Ondanks die feit dat Karel die Grote nog ongetwyfeld met vrome bedoeling die misericordia Dei ${ }^{22}$ bely het, het die menslike hoog. moed al spoedig van die rex gratia Dei gemaak 'n vicarius Dei, wat hom vir sy doen en late beroep op 'n "droit divin". ${ }^{23}$ Spanning tussen owerheid en onderdaan kon uiteraard nie uitbly nie en die kreet „nil Dieu, nil maitre" galm in steeds weerkerende echo tot vandag toe in die toenemende aansprake op sogenaamde onvervreembare menslike regte. Dit val nie te ontken nie, dat én owerheid én onderdaan tot hierdie spanning bydra deur egoïsties die reg, die "dit is myne" toe te eien en geen oog te hê vir die plig respektiewelik om tot aller welsyn God ter ere te regeer en gehoorsaam die deur God daargestelde gesag te aanvaar. In die maalkolk van soewereiniteits-toeëiening deur staat en volk gaan die orde verlore en uit die wanorde word of die despotisme of die oordrewe demokrasie, die demonkrasie gebore. Gesag met gedwonge ontsag, egalité met gedwonge legaliteit is die twee pole wat in verskeurende plukke die orde tot wanorde verpluk.

In die swaaie van die dinastiese tirannie na die terreur van die gepeupel staan die skrifgeinspireerde Calviniste nie aan die onderpunt nie maar baie beslis na aan die bopunt van die pendulum. Aan Calvyn, gebore in Frankryk, sprekende uit Genève en nie aan Rousseau, gebore in Genève, sprekende uit Frankryk, kom die eer toe dat hy die saad gesaai het om Gesag en Vryheid in korrekte perspektief te plaas. Geen wonder dat Doumerque Calvyn noem „le fondateur des libertes modernes" ${ }^{24}$ al sou hy hom die geregverdigde wrewel van Waterink op die hals gehaal het deur Rousseau se vryheidsopvattinge aan die Calvinisme te knoop. ${ }^{25}$ Niemand hoef verbaas op te kyk as die woorde van Bancroft met instemming aangehaal word nie. „The fanatic for Calvinism was a fanatic for liberty, for in the moral warfare for freedom, his creed was part of his army and his most faithful ally in the battle". ${ }^{26}$ Dit alles ondanks die feit dat Calvyn die gesag beklemtoon het in ' $n$ byna absolutistiese sin wat die moderne oor as 'n wanklank sal aandoen. 
Van die Calvinistiese nugterheid bied die tagtigjarige stryd tussen Hollander en Spanjaard die beste voorbeeld. Van die wreedhede wat bedryf is deur Alva in naam van Philips II is die volgende 'n kleurvolle skildering: „No mode in which human beings have ever caused their fellow-creatures to suffer, was omitted from daily practice. Men, women, and children, old and young, nobles and paupers, opulent burghers, hospital patients, lunatics, dead bodies, all were indiscriminately made to furnish food for the scaffold and the stake. Men were tortured, beheaded, hanged by the neck and by the legs, burned before slow fires, pinched to death with red hot tongs, broken upon the wheel, starved and flayed alive. Their skins, stripped from the living body, were stretched upon drums, to be beaten in the march of their brethren to the gallows". ${ }^{7}$ Tog kon Willem die Swyger onder dit alles nog waarsku om nie kwaad met kwaad te vergeld nie; kon hy selfs die soewereiniteit van die Spaanse vors erken, sy dit dan in 'n dokument wat genoem is ' $n$ ",masterpiece of ponderous irony" waarin na ' $n$ hoogdrawende preamble Philips II die volgende in die mond gelê word,$\ldots$ we have resolved, after ripely deliberating with our dear cousin, William, Prince of Orange, stadholder, to erect a free public school and university" 28 - 'n skenking aan die inwoners van Leiden in naam van Philips II juis vir hul aan. deel in die opstand teen dieselfde vors. Sewe jaar later eers het die afswering van Philips II gevolg.

Dieselfde volk wat soveel van sy onderdrukker te verduur gehad het, het die kerkleiers voortgebring wat in die Nederlandse Geloofsbelydenis so kort na hierdie afgryslike gebeure kon bely: „Ons glo dat onse goeie God vanweë die verdorwenheid van die menslike geslag, konings, vorste en owerhede verorden het, omdat dit sy wil is dat die wêreld geregeer moet word deur wette en regeringe, sodat die losbandigheid van die mense bedwing kan word en alles met goeie orde onder die mense kan geskied" - en ook „(ons) verwerp... in die algemeen almal wat die owerhede en regeerders verwerp en die regterlike mag omver wil stoot..." ${ }^{29}$ Nie die "Widerstandsrecht" nie, wat Calvyn so skerp afgewys het, ${ }^{30}$ maar die gees van Romeine $13: 1-7$ spreek uit hierdie belydenis.

Ordening onderstel ' $n$ bepaalde skikking van sake en skikking kan nie plaasvind sonder die hand van 'n beskikker, ' $n$ gesagsarm nie. God in sy majesteit regeer oor die volke as 
Beskikker van heel hul lewenslot, regeer ook instrumenteel deur die gesagsorgane. Laasgenoemde moet ook hierin sy beperkinge sien. Die afgeleide soewereiniteit van alle menslike gesag het sy perke, het sy deur God verordineerde kring. Beter as Kuyper kan ek dit nie stel nie: „... aan het Calvinisme komt de eere toe, tegen dezen absolutistischen stroom een dam te hebben opgeworpen, niet door een beroep op volksgeweld, noch op waan van menschelijke hoogheid, maar door die rechten en vrijheden der maatschappij te hebben afgeleid uit dezelfde Bron waaruit het hoog gezag der Overheid vloeit, t.w. uit de absolute souvereiniteit Gods... Een volk dat het gezinsrecht of een universiteit die het recht der wetenschap veil biedt aan owerheidsinmenging, staat even schuldig voor God, als een natie die zich aan het overheidsrecht vergrijpt. En zoo is de strijd voor de vrijheid niet slechts voor geoorloofd verklaard, maar zelfs tot plicht gesteld voor een ieder in zijn kring, niet door, gelijk in de Fransche revolutie, God opzij te zetten en den mensch in den troon der Almacht te plaatsen, maar juist door alle mensch, den magistraat incluis, diep eerbiedig te doen buigen voor de majesteit van den almachtigen God".31

Alles wat blink is egter nie goud nie. Die Calvinis is ook verdorwe mens en toon in elke geslag ook maar die ondeugde van sy tyd. Heersersug wat met 'n vroom beroep op die voorsienigheid Gods die gevolge van sy dade vergoeilik is nie minder te veroordeel nie as die ,gepraedestineerde dief" van die Arminiaanse predikant, Henricus Slatius, wat die Gereformeerde predestinansieleer ' $n$ fatalistiese kleur gee en daarmee God tot outeur van die sonde maak. Ongehoorsaamheid teenoor gesag is helaas onder ons ook geen rariteit nie, al doen dit sig voor in die onskuldiglykende maar minder eerlike afknyp van dit wat die Ontvanger van Inkomste wetlik toekom.

Ten slotte ' $n$ enkele gedagte oor dit wat Teoloog en Regsgeleerde nog te doen staan in verband met die omlyning van Gesag en Ordening. Soewereiniteit in eie kring is ' $n$ pragtige adagium maar behoef tog skerper omlyning. $\mathrm{Na}$ die fenomenale industriële ontwikkeling van die afgelope eeu en na Karl Marx as die gewetenstem teen die uitwasse van die kapitalisme in luider klank Proudhon se „La propriété, c'est le vol" aangehef het, kon die stroom van sosialisering nie gestuit word nie. Die noodsaaklikheid van ' $n$ ingrype deur die staat lyk in die 
gekompliseerdheid van ons moderne samelewing na 'n logiese noodwendigheid vir hom wat die praktiese politiek moet bedryf. Om alle staatsmonopolistiese neigings sienderoog toe te laat, is nie verantwoord nie. Aan die ander kant lyk die afwys van alle sosialiseringstendense soos Van Riessen voorstaan, ${ }^{32}$ vir my tog 'n bietjie na leunstoelgeleerdheid, hoewel ek groot waardering het vir sy tydig waarskuwende spreke. Waar die Calvinistiese geleerde nog altyd gestreef het om die balans te vind tussen alle verabsoluteringe van -ismes, lê hier ' $n$ belangrike studieveld braak.

\section{Geregtigheid}

Geregtigheid - net soos in verband met tyd, kan die woorde van Augustinus hier herhaal word: „As iemand my dit vra weet ek dit wel, maar as ek dit aan iemand moet uitlê weet ek dit nie". ${ }^{33}$ Geregtigheid is iets wat die heiden onder Gods Gemene Grasie of soos Dooyeweerd dit noem Gods tydelik konserverende genade in die hart gevoel, maar wat selfs die gelowige in woorde nie reg kan bevredig nie. Die gepositiveerde reg is en sal steeds bly 'n benadering van die ware geregtigheid, maar hierdie strewe na die jus optimum gee aan Justitia 'n gewyde karakter, soos Kuyper dit êrens stel „Justitia of sancta moet blijven, of ophoudt Justitia te zijn". ${ }^{34}$ Hier meen ek is ' $n$ verwysing na die Romeinse reg nie onvanpas nie. Dit is tog sekerlik nie toevallig nie dat Christus gebore is en sy omwandelinge op aarde belewe het in ' $n$ tyd toe die hooggeroemde Romeinse reg sy toppunt bereik het. 'n Apostel soos Paulus het met trots hom op sy Romeinse burgerskap beroep en seker met vertroue, vir sover vertroue in die menslike kan gaan, Festus rede gegee om te sê: „Op die keiser het jy jou beroep - na die keiser sal jy gaan". ${ }^{35}$ Die Verlosser van die wêreld moes die oordeel van God verduur in 'n tyd waarin die relatiewe geregtigheidsgehalte hoogaangeprys die imperium $R_{0}$ manorum deurgalm het. Die Geregtigheid Gods moes die hooggeroemde menslike geregtigheid met 'n beskaamde aangesig laat. Dit alles neem nie weg nie dat die Romeinse reg as jus bonum et aequum selfs 'n diepgelowige soos Calvyn tot bondgenoot was in sy samestelling van 'n siviele prosesregkode vir Genève, al het dit plaasgevind in 'n diepliggende afsku vir die Kanonieke reg wat ironies genoeg sy Romeinse karakter hoog 
geroem het in die personaliteitsbeginsel „ecclessia secundum legem romanam vivit". Tog moet Calvyn se beroep op die Romeinse reg nie te hoog aangeslaan word nie. Die groot hervormer is deur Melanchton genoem die teoloog by uitnemendheid, maar dieselfde kan ondanks verdienstelikheid in die rigting nie van sy juridiese arbeid gesê word nie. Hoewel in Bourges onder meer onderrig deur die groot Italiaanse voorloper van die Franse humanistiese skool nl. Andreas Alciatus en in Strassburg na alle waarskynlikheid bekend geword met die geskrifte van Ulrich Zasius, die Freiburgse professor en ander grondlegger van dieselfde skool, het Calvyn nog sterk gesteun op die werke van die kommentatore wat deur die bekende Cujaccius gehekel is in 'n taal wat geen teologiese odium oneer sal aandoen nie: „verbosi et prolixi in re facili, in difficili muti, in angusta diffusi", 36 Gelukkig het Calvyn sy geregtigheidsbeginsels nie net gesoek in die mense-skeppinge nie maar ook die menslike geregtigheid gesien as 'n floue weerskyn van die Bron van alle Geregtigheid, al was daar by homself 'n fale in hierdie deug met name in die beoordeling van Servet.

Hoewel daar oor die geregtigheid baie gefilosofeer en gedelibereer kan word en hoewel ek my bewus is van die gevaar om „Tekststufenkunde" te bedryf, meen ek tog dat die Bergpredikasie in sy byna poëtiese skoonheid oor hierdie onderwerp geen teologiese of juridiese weerga in waardigheidsgehalte vind nie. Luister maar. "Salig is die wat honger en dors na die geregtigheid, want hulle sal versadig word. Salig is die vredemakers, want hulle sal kinders van God genoem word. Salig is die wat vervolg word ter wille van die geregtigheid, want aan hulle behoort die koninkryk van die hemele. Want Ek sê vir julle dat, as julle geregtigheid nie oorvloediger is as dié van die skrifgeleerdes en Fariseërs nie, julle nooit in die koninkryk. van die hemele sal ingaan nie... seën die wat julle vervloek, doen goed aan die wat vir julle haat, en bid vir die wat julle beledig en julle vervolg; sodat julle kinders kan word van julle Vader wat in die hemele is; want Hy laat sy son opgaan oor slegtes en goeies, en Hy laat reën op regverdiges en onregverdiges. Maar soek eers die koninkryk van God en sy geregtigheid, en al hierdie dinge sal vir julle bygevoeg word. Moenie wat heilig is, aan die honde gee nie; en gooi julle pêrels nie voor die varke nie, sodat hulle dit nie miskien met die pote vertrap en omdraai en julle verskeur nie. 
Alles wat julle dan wil hê dat die mense aan julle moet doen, net so moet julle aan hulle ook doen; want dit is die wet en die profete".

Daar staan geskrywe dat die mens van brood alleen nie kan lewe nie. Dit geld ook van die reg. Die Bybel stel sowel die gemeenskapsordening as die subjektiewe regsuitoefening in gebreke. Wanneer die regsmiddele uitgeput is, dan bly vir die mens niks anders oor nie as om terug te keer tot die bron van die reg, die Genade van God, en daarin te vind die versoening van die teenstelling veroorsaak deur die reg. ${ }^{37}$

\section{Die mens as regssubjek}

Ondanks die mens se nietigheid; in fisiese sin selfs in vergelyking met die dier - ondanks die mens se verdorwenheid; verdorwe tot so 'n mate dat die redelose dier in geraffineerde wreedheid die bestialiteit van die mens nie kan nadoen nie - ondanks die in klip gebeitelde erkenning van „Man's inhumanity to man" - tog is die mens kroon van die skepping. Tog is die mens geroepe tot heerskappy oor die skepping. Tog is die mens onder die soewereiniteit van God subjek in al die te bedinke wetskringe. Tog is die mens in die reg draer van regte en verpligtinge. Subjek en nie objek nie. Iets hiervan het die heidense Romein tog begryp: ondanks die objektivering van die mens tot voorwerp van saaklike reg, tot servus, tot res wat aan die dominium ex jure Quiritium van sy heer en meester onderhewig is, kon die erkenning dat die slaaf ook mens is die aandag nie ontgaan nie. Die skepping van die actiones adiecticiae qualitatis is daar 'n klinkklare bewys van. Die heer het dikwels sy slaaf gebruik om regshandelinge met derdes aan te gaan. Die derde het egter met die probleem bly sit dat hy die slaaf nie kon aanspreek nie omdat lg. nie regsubjek is nie, en ook nie die heer kon aanspreek nie omdat die slaaf nie sy heer kon belas nie. Hierdie handelsbelemmerende omstandigheid is omseil deur aan die derde tog in verskillende omstandighede verskillende actiones teen die heer toe te staan. Toegegee dat die slaaf nie hiermee vry geword het nie en ook nie regsubjektiwiteit verwerf het nie, is by implikasie tog sy menswaardigheid, sy met rede begiftigde karakter erken. Opmerklik is dit dat die praetoriese prosesformulae selfs waar na die slaaf as objek verwys word die uitdrukking ,homo, quo 
de agitur" verkies.

In die Germaanse reg was die posisie blykens die gegewens in Tacitus se de origene et situ Germanorum enigsins anders, ${ }^{38}$ en Hugo de Groot kom in die beginjare van die Republiek der Verenigde Nederlanden reeds aantoon dat slawerny onbekend is, behalwe in die kolonies, hoewel vorme van horigheid tot laat in die 18e eeu nog in Gelderhand en Overijssel voorgekom het. ${ }^{39}$

Dat ooreenkomstig Christelike beginsels die gebruik van 'n mens as willose werktuig ' $n$ vergryp is aan die menslike in die mens, en daarom ongeoorloofd, behoef geen uitvoerige betoog nie. Mens staan egter verwonderd by die feit dat dit soveel eeue moes duur voordat hierdie maatskaplike wantoestand sy uittrede gedoen het. Al is dit so dat die Christendom verwyt kan word dat hy vir eeue sy stem teen slawerny nie sterk genoeg laat hoor het nie, en al is dit so dat minder suiwer krete teen die mensgevormde ongelykheid die Christendom in ywer beskaam het - tog val nie te ontken nie dat ' $n$,wijziging in het zedelijk bewustzijn omtrent de rechtmatigheid der slavernij en deze omzetting van de slawernij in de vrije dienst. betrekking is metterdaad te danken aan de doorwerking van de Christelijke beginselen, dat alle Christenen, als kinderen van den éénen Vader, broeders, en alle menschen, als geschapen naar Gods beeld naar hun wezen gelijk zijn".40 Oor slawerny as sodanig wens ek $u$ nie verder te vermoei nie. Daar is egter ander vorme van objektivering van die mens wat wel ons aandag verdien.

Van der Keessel maak in sy voorlesinge na aanleiding van De Groot se "Inleiding tot de Hollandse Rechtsgeleerdheid", die volgende sonderlinge stelling: „Monstra pro hominibus non habentur sed, ut Grotius ait, statim suffocantur... Et si vel minimum dubii supersit, mihi quoque placet consilium Leyseri, ut expectetur, usque dum maturior aetas doceat, sitne homo rationalis an animal brutum..." 41 Hierdie stelling kom nog meer vreemd voor as in gedagte gehou word dat Van der Keessel met 'n beroep op D. 50.16.38 en D. 12.1.10.2 pas voor die bo aangehaalde stelling sê: „As gebore mense geld alleen diegene wat 'n liggaam het geskik en bevatlik vir 'n redelike gees. Hierdie definisie van De Groot toon duidelik aan dat ook verskynings en wanstaltige geboortes wat iets onnatuurliks het tog as mense geld". ${ }^{42}$ Dit wil voorkom asof hier 'n graduele 
verskil tussen wanstaltige geboortes en monstra geïmpliseer word. Tog vertaal Gonin C. S. monstra met „wanskape misgeboortes" wat tot misverstand kan lei, omdat in mediese parlance daar nie van lewensvatbaarheid sprake is by 'n misgeboorte nie. Wat presies onder monstra verstaan word kan ons daar laat om ons met die prinsipiële besig te hou.

Uit Van der Keessel se betoog blyk dat vroeg in die vorige eeu hierdie praktyk om heer oor lewe en dood te speel in dié besondere omstandighede toelaatbaar geag is, al word dit onderworpe gestel aan die oordeel van die regssprekende amptenaar en bedrewe medici.

Hoewel hierdie praktyk tans nie meer openbare aandag geniet nie en dus sekerlik nie meer openlik plaasvind nie, sal ek my liewer nie daaraan waag om te spekuleer wat in die verborgene plaasvind nie. Gods Genade spreek ook uit dit wat ons in die natuur ervaar nl. dat wanstaltig gebore mense in die reël die lewe nie lank behou nie. Dit egter gee allermins die mens die reg om met mediese of ander ingrype die lewe te verkort. Dit bring ons by die eutanasie wat geleidelik besig is om quasi-burgerreg te verkry in die sedelike bewussyn van die moderne mens. Von Liszt het aan die begin van hierdje eeu de lege ferenda die volgende "Sonderbestimmung" voorgestel vir $\S 216$ R.S.G.B.:

„Wer durch das Verlangen des Getotenten oder durch den hoffnungslosen Gesundheitszustand einer ihm nahestehenden Person zur Totung bestimmt worden is, wird usw" ${ }^{43}$ Dit moet toegegee word dat hiermee nòg eutanasie nòg deelneming aan selfmoord gesanksioneer word tot die straflose, maar die spore van 'n neiging tot mildheid is in hierdie "Sonderbestimmung" tog vervat. Die probleme wat die Strafregsistematiek het by die strafbaar-stel van deelneming aan en aansetting tot selfmoord kan ek hier nie breedvoeriger uiteensit nie. Ek volstaan met 'n stelling wat die Expertenkommission by die bespreking van die Ontwerp van die Switserse Strafreg-Wetboek geuiter het: „Die Anstiftung zum (en ek sal graag byvoeg: und Teilnahme am) Selbstmorde kann ja auch hach Umständen einem Morde oder Todschlag nicht nur moralisch sondern auch rechtlich gleichkommen". ${ }^{44}$

Die subjeksyn van die mens, ja, tot sy laaste asemtog toe, moet weer eens in groot letters geskryf word: Raak die kroon van Gods skepping nie aan nie; verlaag dit wat God met 'n 
rede begiftig het, nie tot objectum juris nie.

'n Enkel woord nog oor 'n ander vorm van objektivering van die mens. Den Hartogh het in ' $n$ artikel oor die reg die volgende beweer: „...de overheid, wanneer zij naar antirevolutionair of christelijk-historisch beginselen te waken heeft tegen het bordeelwezen, het souteneurschap, openbare dronkenschap en anderen publieken aanstoot, zij zulks ... te doen heeft ... als handhaafster van het natuurrecht. Immers bordeelwezen en souteneurschap verlagen de mensch van rechtssubject tot rechtsobject en schenden daardoor het politisch natuurrecht, evenzeer als de publieke aanslagen op de eerbaarheid de openbare orde in de samenleving en daarmede Gods ordinantie aanranden". ${ }^{45}$ In Suid-Afrika is dit weliswaar nog nie so dat bogenoemde euwels met owerheidsreëling toegelaat word nie. Die utilistiese redenasie dat prostitusie in elk geval plaasvind en dat dit daarom beter is om die prostitusie te orden eerder as om dit oogluikend ongeorden te laat, kan egter onder die onstuitbare toename van hierdie sonde, die owerheid verlei tot aanname van sodanige ordening. Dit mag nie. Die beginsel dat die mens subjek en nie objek in die reg is, mag nie wyk vir die onuitroeibaarheid van hierdie vorm van liggaamsverslawing nie.

\section{Sonde, misdaad en onregmatige daad}

Daar is meermale al beweer dat die reg die etiese minimum reël, dat „(die Religion und) die Sittlichkeit wollen keine Diebe, keine Môrder, keine Ehebrecher; das Recht will keine Bestohlenen, keine Ermordeten, keine betrogenen Ehegatten".46 Hoewel enigsins simplisties gestel bevat hierdie stelling genoeg. same waarheid om dadelik te laat aanvoel dat sonde aan die een kant wel te onderskei is van misdaad en onregmatige daad aan die ander kant. Ook betreklik simplisties gestel, sal gesê kan word dat 'n misdaad 'n ,onregmatige daad" is wat by oortreding met straf besoek word terwyl 'n onregmatige daad nie met straf bedreig word nie maar aanleiding gee tot 'n siviele eis teen die dader. Vir my verdere betoog sal dit nie nodig wees om tussen misdaad en onregmatige daad te onderskei nie en beperk ek my tot die teenstelling sonde en misdaad in die verwagting dat $\mathrm{u}$, waar toepaslik, mutatis mutandis die teenstelling sonde en onregmatige daad sal raaksien.

Byna onmoontlik klink dit vir die twintigste-eeuse oor 
dat ' $n$ bepaalde strafregter kon meegewerk het aan nie minder nie as 20,000 doodvonnisse. Tog word dit beweer van die beroemde Leipziger geleerde, Carpzovius wat ironies genoeg die voornaam Benedictus gedra het. Geen wonder dat die strafregstelsel en strafregpleging van 'n tyd waarin so iets moontlik was, d.i. voor die $19 \mathrm{e}$ eeu, genoem is 'n "samenstel van wreedheid en onverstand". 47

Die byna ligvaardige aanname dat skuld en aanspreeklikheid bepaalbaar is, gepaardgaande met die sombere oordele wat daaroor uitgespreek is, het onder die gehekel van die vlymskerp penne van Voltaire en die jeugdige Cesare Bonesana, Markies van Beccaria, geleidelik begin wyk vir 'n toenemende humanisering van die strafregpraktyk. Enkele stemme van verset kon die stroom nie stuit nie. 'n Franse kriminalis probeer dit nog in 1771 met die volgende woorde oor Beccaria se pleitskrif: „Ce Traité des delits et des peines..., tend à etablir un système des plus dangereux et des idées nouvelles qui, si elles etaient adoptées n'iraient à rien moins au'a ren. verser les lois reçues jusqu' ici par les nations les plus poliçeés, et donneraient atteinte a la religion, aux moeurs et maximes sacreés du gouvernement". ${ }^{48}$

Ná die angswekkende geweld van die stormgety wat in 'n verwoestende kragsontplooiing die water oor die hoogwatermerk laat donder, volg dikwels die ewe gevaarlike slepende, suigende krag van die wegsinkende see. Ook hier. Die resultate van die werk van die psigiater, Lombroso en ander het tot gevolg gehad 'n gekanker aan die vrye-wilsteorie en het 'n impetus verleen aan die intrede van die determinisme. Die punitur quia peccatum est moet wyk vir die punitur ne peccetur. Straf moet wyk vir behandeling. Nie die afkeurenswaardige daad nie maar die sieklike dader is van belang - die vraag is of hierdie oordeel nie soms gevolg is van 'n ewe sieklike jammerhartigheid nie. Die rasionalistiese hoogmoed begin seëvier en die mens roep in selfverheffing uit dat „unbefange Anhänger des gesunden Menschenverstandes unmöglich dem Wahne der Willensfreiheit huldigen können", ${ }^{49}$ en nog betreklik onlangs "Die Zukunft des Strafrechts liegt in seiner Aufhebung, d.h. in der Entfernung jedes Recht zur Strafe".,50 By al die onverstand wat in die naam van die gesonde Menseverstand bedryf word, moet ons egter nie sonder waardering wees vir die positiewe in die hoofsaaklik deterministies-gekleurde antropologie en 
kriminologie nie. Die woorde van Christus „Moenie oordeel nie, sodat julle nie geoordeel word nie", waarmee sekerlik - nie alle oordeel bedoel word nie maar juis die ligvaardige oordeel, kry vir ons nuwe betekenis in die studie van die nie te ontkenne oorsake van misdadigheid. Ek wil dan ook hierdie geleentheid te baat neem om 'n ernstige pleit te voer vir die instelling van Kriminologie as vak aan hierdie universiteit. Hoe gevaarliker die idiologiese implikasies van kriminologies-wetenskaplike resultate, des te dringender die noodsaak om dit in die lig van Gods Woord te bestudeer. Net so min as wat ons die terrein van plant- en dierkunde mag vermy omdat die evolusieteorie sy hand daarna uitgesteek het, net so $\mathrm{min}$ is dit verantwoord om die kriminologie uit angsvallige vrese langer ' $n$ plek in die wetenskapskonstellasie te ontsê.

Die opkoms van die Determinisme het tot dusver nog nie 'n ernstige bedreiging vir die Suid-Afrikaanse strafreg geword nie. Ek meen dat dit toegeskryf moet word aan 'n weerstand wat selfs by ons lou Christelike en onchristelike medeburgers bewerk is deur die diepgewortelde oortuiging van die Calvinis dat die mens nie sy skuldverantwoordelikheid kan ontduik met 'n beroep op 'n ,ek kon nie anders gehandel het as wat ek gehandel het nie". Die tekens van wat kom is egter daar en Swanepoel het dit reeds nodig gevind om die stryd tussen indeterminisme en determinisme op strafreggebied vir die Republiek aan te dui as van fundamentele belang.".1

In Duitsland het ongeveer twee jaar gelede ' $n$ felle stryd ontbrand ná die aankondiging van 'n wetsontwerp vir 'n nuwe strafregkode wat in wese nog gebaseer is op die tradisionele skuldaanspreeklikheid. Die „permissive society”-gedagte wat van geen normatiewe eise iets wil weet nie neem Europa reeds stormenderhand oor, en ek voel my ongerus dat die kabbelende geklots van dieselfde gevaar ons vaderland aan die slaap kan sus. Die véraf gedonder teen die doodstraf bring ons slegs tot ' $n$ sluimerende wake uit die doodslaap. Alles aanduidinge dat die penetrasievermoë van die determinisme geensins onderskat moet word nie.

Wat het dit alles nou te make met Openbaring, Teologie en Reg!

Reeds eerder het ek beklemtoon dat sonde en misdaad nie identiek is nie. Met die intrede van die sonde egter was die weg gebaan vir die positivering van die misdaad. Misdaad son- 
der sonde is ' $n$ ondenkbaarheid en die hipotetiese goed en gaaf geskape mens van Jean Jacques Rousseau sal onmoontlik die eén kon bedryf sonder om hom aan die ander te besondig. Ondanks die feit dat sonde en misdaad nie identiek is nie, bly dit waar dat „naar Christelijk geloofsstandpunt het diepste wezen der misdaad in de zonde en dat de straf, ook de staatsstraf, in den goddelijke gerechtigheid gelegen is". 52

Determinisme en indeterminisme, net soos Tyd en Ewigheid, beperkte ruimte en oneindigheid appeleer op die menslike logika sonder logies versoenbare sintese van die teenstrydigheid. Verwyte oor en weer van onwetenskaplikheid in die aanvaarding van 'n bepaalde geloofsuitgangspunt is in dié verband absoluut sinneloos. Die waarheid bly met 'n enkele belangrike reservering dat ,het probleem niet vatbaar (is) voor oplossing, omdat wij, allen, telkens weer, onderhevig blijken aan de aantrekkingskracht, de invloed, de bekoring én van de gedachte aan de vrije wil én van die gedachte aan het determinisme". 53 Die reservering wat ek wil voorhou lê daarin dat die probleem alleen nie vatbaar is vir oplossing nie in sover 'n dwingende keuse gelaat word tussen determinisme en indeterminisme. Geeneen van beide het ter uitsluiting van die ander reg op die "cachet" van Die waarheid nie. Daarom dink ek dat die grote Kuyper ontydig en ietwat ondeurdag, hoewel erg versigtig, die moderne determinisme ingeroep het as apolegeet vir die Calvinistiese geloof in die voorbeskikking van God. ${ }^{54}$ Nòg die deterministiese (fatalistiese) ontkenning van menslike verantwoordelikheid, nòg die indeterministiese (Arminiaanse) ontkenning van 'n Goddelike voorbeskikking het 'n plek op Calvinistiese erf, en dit betaam nie dat ons soos Art. XIII van die Nederlandse Geloofbelydenis dit stel „met betrekking tot die dinge wat Hy doen bo die begrip van die menslike verstand... 'n nuuskierige ondersoek instel wat ons begrip nie kan bevat nie".

Dit is geensins my bedoeling om die drie formuliere van eenheid gebaseer op Gods Woord hier te resumeer nie. En Gods ewige Raadsplan, sy onbegryplike voorbeskikking wat in die onderhouding van die skepping niks aan die toeval oorlaat nie, én die menslike verantwoordelikheid, die menslike sondeskuld en daarmee implisiet die misdaadskuld wat alleen deur die geloof in Jesus Christus versoen kan word, blyk hierin ten oorvloede. Ons glo onwrikbaar aan albei dié grondstellinge, 
en daarom kan ons dit nie slegs Sondag aanhoor nie maar moet ons dit ook van Maandag tot Saterdag verkondig; verkondig ook in die regscollege. Dat die reeds verrigte teologiese arbeid op die gebied ons wapenbroeder in die stryd is, wil ek weer eens beklemtoon. Werke soos Geesink se „Van 's Heeren Ordinantiën”, Dyk se „Om 't eeuwig Welbehagen" en Berkouwer se twee werke „De voorzienigheid Gods" en „De verkiezing Gods", om maar enkeles te noem, bly ook vir die juris deel van sy wapentuig.

\section{Die doodstraf}

Onbekookte argumente vir en teen die doodstraf word tans weer in Suid-Afrika die lou-oond ingedruk om as opgewarmde, onsmaaklike spyse die leserspubliek aangebied te word. Sommige van die argumente ter afskaffing van die doodstraf word selfs met die pretensie van 'n Christelike etiket ons in die ore geblaas. Al die argumente vir en teen die doodstraf is nie nodig om hier herhaal te word nie. As gelowiges moet ons die doodstraf vir doodslag onderskryf, al moet ons erken dat baie argumente vir die behoud van die doodstraf op blote doelmatigheid berus en daarom nie ons aandag werd is nie. Voor Gods Woord moet ons egter swig en geen geskipper met menslike slimmighede kan daarteen iets vermag nie. Selfs die jammerlike gekef teen die doodstraf op grond van 'n quasi-christelike pretensie kan ons daarlaat en wel omdat 'n positiewe stelling van wat Gods Woord ons leer, dit geheel en al ontsenu.

Vir wat hier volg het ek my byna uitsluitend verlaat op wat Kuyper in sy „De Gemeene Gratie” so skitterend uiteensit. Kuyper self erken dat sy uiteensetting nie nuut is nie, maar ek is my nie bewus van 'n deegliker en meer sprekende stel van hierdie onderwerp nie. Die argumente wat Kuyper nodig ag om te ontsenu stem in so 'n mate ooreen met die argumente wat ons tans moet aanhoor dat ons waarlik kan uitroep dat daar niks nuuts onder die son is nie.

Genesis 9:6 lui: „Hy wat die bloed van 'n mens vergiet, sy bloed sal deur die mense vergiet word; want God het die mens na sy beeld geskape". Om hierdie teks draai alles. In klare lig moet dit gestel word dat hier nie 'n blote ervaringswerklikheid geponeer word nl. dat algemeen ondervind word dat hy wat bloed vergiet sy dag wel sal kry nie. Die impe- 
ratiewe bevel in hierdie teks lê opgesluit in die redegewende laaste gedeelte daarvan $\mathrm{nl}$. „want God het die mens na sy beeld geskape". Alle sin word hierdie gedeelte ontneem indien die eerste gedeelte van die teks nie opgeneem word as 'n verpligting deur God die mens opgelê nie.

Dit alles is waar, word vandag weer gesê, maar die Nuwe Testament gee tog ' $n$ ander beeld. Hieroor laat ek Kuyper self die woord voer: „... de tegenspraak houdt nóg aan, en kleedt zich nu in deze vorm. Het is wel zoo, dat God destijds de doodstraf verordent heeft, maar dit geldt daarom niet meer voor ons. Wel voor de dagen der barbaarschheid, niet in onze eeuw van hoogere beschaving, vrucht van het Evangelie des Nieuwen Testaments. Dat alles is nu afgeschaft, evenals alle soortgelijke wetten van het Oude Verbond. Dit komt er dus op neer, dat men het wel over de uitlegging van Gen. $9: 6$ met ons eens is, maar nu toch weer tegenover ons gaat staan, omdat, zoo het heet, Gen. $9: 6$ thans niet meer zou gelden. Op deze tegenspraak nu kan ons antwoorde kort zijn.

Vooreerst dan dit. Waar staat dat deze ordinantie Gods is afgeschaft? Erkent ge dat God het toentertijd zoo verordend heeft, dan blijft uiteraard deze ordinantie gelden, totdat God zelf ze intrekt of opheft... Zoolang dit niet geschied is, blijft ze gelden. Van zulk een afschaffing of intrekking nu lezen we nergens. En zegt men, Ja, maar door het Evangelie is welbezien heel het Oude Testament, en derhalwe ook dit gebod vervallen, dan betwisten we dit... al geldt dit vervallen bij hetgeen aan Israel verordend werd, dan toch... er is van geen wegvallen hoegenaamd sprake bij hetgeen God verordend heeft eer die bedeeling der schaduwen er kwam. In die vór Israëlietische bedeeling heeft God verordend, dat de man werken zal in het zweet zijns aanschijns om brood te eten; dat de vrouw met smart haar kinderen zal baren en zooveel meer. Is dit alles nu afgeschaft onder het Nieuwe Verbond, of is het gebleven? En als ge antwoordt: Natuurlijk gebleven, wat recht hebt ge dan om te zeggen, dat het gebod van de doodstraf wel wegviel?" ss

Twee ander argumente wat gekleed gaan met vroomdoende Christelike besorgdheid is $\mathrm{nl}$. dat die bekeringstyd van die misdadiger afgesny word en dat die strafregter dalk 'n onskuldige ter dood kan veroordeel het. Oor geen van beide argumente hoef ons veel asem te mors nie. Wat God gebied moet 
onvoorwaardelik uitgevoer word en nòg die bekering van die moordenaar nòg die moontlikheid van menslike fale in die oordeelsbevinding mag in die weg staan van hierdie uitvoering. Die bekering van die sondige mens is in elk geval nie ' $n$ saak van vryewilsbesluit vir die „aspirant bekeerling” nie. Kuyper stel ook dit duidelik: „Is er dus van doodstraf sprake bij een door God uitverkoren persoon, dan kan geen doodstraf zijn zaligheid afsnijden; want, die Hij te voren verordineerd heeft, deze heeft Hij ook geroepen; die Hij geroepen heeft, deze heeft $\mathrm{Hij}$ ook gerechtvaardigd; en die $\mathrm{Hij}$ gerechtvaardigd heeft, deze heeft Hij ook verheerlijkt".56 Buitendien, as die erns van die doodvonnis 'n moordenaar nie tot sielsverbryseling bring nie, val dit nie in te sien hoe die spaar van sy lewe die klip in sy hart sal vermurwe nie.

Dat 'n onskuldige skuldig bevind kan word, is waar en dat dit al gebeur het vervul ons met afgryse. Bekende voorbeelde is die van Dreyfuss en heelwat vroeër die teregstelling van Jean François Calas, wat in 1762 te Toulouse weens 'n regsdwaling onskuldig ter dood veroordeel is. Laasgenoemde gebeure was juis die aanleiding vir die reedsvermelde geskrif van Voltaire. Aanleiding tot die afskaffing van die doodstraf mag hierdie argument nie gee nie; wel moet dit ons onder die diepe besef bring van die ontsettende verantwoordelikheid wat op die skouers van die strafregter rus. Waarlik vreemd is dit egter dat dieselfde mense wat hul tog so besorgd maak oor foute wat die regter mag maak, dikwels die regter veroordeel omdat hy by gebrek aan bewys die beskuldigde onskuldig bevind, terwyl onder die gekwetter van skinderbekke dié arme drommel reeds skuldig in hul wete is.

In verband met die doodstraf is daar tog iets waaroor ernstig besin moet word. Hierdie straf word tans in Suid-Afrika toegepas nie net in geval opsetlike doodslag nie maar ook waar ander misdade gepleeg is, onder meer die misdaad, verkragting. Minder te doen as wat God verordineer het, mag nie maar om te wil doen wat God nie verordineer het nie is met betrekking tot die doodstraf nie verantwoord nie. Wraakgevoelens by die mens teen iemand wat verkragting gepleeg het, veral as die slagoffer 'n nog seksueel-onrype kind is, mag ons nie daartoe verlei om maar goedsmoeds die doodstraf hiervoor in te voer nie.

Die wyse waarop die doodstraf voltrek word is hier nie 
ter sake nie, maar uitgerekte en onmenslike marteling word nêrens in Gods Woord gebied nie en is inteendeel in stryd met die liefde wat Christus ook teen die diep in sonde vervalle mens betuig. Die woorde van 'n uitgesproke determinis vertolk hier tog die Christelike menslikheid: „Our attitude to the delinquent should be that of hating the thing he has done but without hating the man". 57

\section{Regsetiek}

Die Middeleeuse kreet „Gute Juristen, böse Christen" is bekend en niemand minder as Luther nie het gesê: 'n Juris kan wel 'n skalk (skelm) wees, maar by 'n teoloog hoort „ein frommer Mann". Dergelike minder vleiende woorde kom ook vandag voor. In 'n Franse werk laat die skrywer een van sy karakters so ongeveer die volgende sê: „Die reg soos bekonkel deur slim en hoogsgerespekteerde skurke bly nog steeds die beste rigting vir 'n loopbaan van eerbare en gemaklike plundering". . $^{\mathrm{s}}$ Die wegwyser word in die volksmond 'n predikant genoem omdat hy die weg aanwys maar dit nie bewandel nie. Hierdie soort kriptiese opmerkinge kan maklik ontsenu word deur 'n beroep te doen op die leek se gebrek aan ware insig, maar dit is heel dikwels so dat 'n enkeling sy hele beroep in diskrediet bring en aanleiding gee tot halwe waarhede wat in die volksmond bly steek. Die optrede en handelwyse van regter, advokaat en prokureur is hier ter sprake. Meermale word van die buitestaander die versugting gehoor dat 'n regsgeleerde van 'n „tegniese punt" gebruik gemaak het om sy kliënt se saak te bevorder en bygevolg sy opponent se saak verongeluk het. So eenvoudig steek sake darem nie inmekaar nie, en wat veelal 'n „tegniese punt" buite die hof genoem word is deel van die objektiewe prosesreg en bewysreg wat om gewigtige redes gehandhaaf word. So bv. hou die reg rekening met die feit dat sekere getuienis te veel subjektiewe „bewys-krag" het; meer as wat by objektiewe nugtere denke toelaatbaar is. Ons dink hier aan 'n situasie wat die hof al uit ervaring geleer het om met versigtigheid te hanteer: die gewetenlose meisie wat 'n man aankla van onsedelikheid en dan met toneelemosie, met trane en al, haar selfgeskeurde flenter-drag as corpus delicti die hof indra. Hier is getuienis aliunde gebillik en noodsaaklik al is die meisie hoe geloofwaardig. Daar is wel formele regsreëls wat 
' $n$ bepaalde ratio het maar wat in billikheid toegepas moet word. Só is die reëls wat ' $n$ tydsbeperking stel op die indiening van hofdokumente gerig op die spoedige beëindiging van die geskil. 'n Prokureur of advokaat wat van hierdie reëls misbruik maak wetende dat sy geleerde vriend, soos hy sy opponent in die hof pleeg te noem, te min tyd gelaat word, handel onbil lik, ook al val sy beswaar streng binne die genoemde regsreël.

Om in te gaan op al die probleme van regstegniek is onmoontlik, maar ek wil met klem daarop wys dat juis op hierdie gebied dit so moeilik val om positief die Christelike beginsels te verbind met die praktyk. En tog is dit hier, waar die Christelike juris sy plig voel om homself te onderskei van sy neutrale kollega maar dikwels nie weet hoe nie. Hy verwyt sy universitêre opleiding, en miskien tereg, met 'n redenasie wat soos volg lui: „Ek weet wat deur die eeue oor die reg gesê is; ja van Plato tot Dooyeweerd, van Augustinus tot die huidige geslag teoloë, van Hammurabi en Solon tot Mommsen en Lord Denning; die Twaalf tafels tot die Deutsche Burgerliche Gesetzbuch is my bekend, ook die Tien Gebooie, die Twaalf Artikels en die Belydenisskrifte is my nie vreemd nie - Tog, hier sit ek. My kliënt wil met 'n egskeidingsgeding begin. Wat moet ek doen? Maak dit verskil of hy medegelowige is of nie? My ander kliënt word aangekla van 'n misdaad - ek glo nie sy verhaal nie; mag ek hom laat onskuldig pleit om sodoende 'n geleentheid te hê om die bewyslas op die staat te werp? Wat moet ek dink van die eedsafleging? So vermenigvuldig die vrae.

Oplossings wil ek nie hier aan die hand doen nie, maar ek wil tog die pleit voer dat ons die Christelike beginsels minder in abstracto en meer in concreto ons studente meegee. Dink ons daaraan dat die probleme i.v.m. die egskeidingsgronde nog voortdurend die sinodale agendas bereik, dan lê daar op die gebied van die Etiek vir teoloog en juris nog groot velde braak; afsonderlik maar ook gesamentlik.

\section{Slot}

Uit die wêrelddeel waar die Bybelwoord onder Gods Inspirasie hoofsaaklik geskryf is, ruis onder rustige palmbome die Oosterse groet ons ter ore - Vrede! Uit die wêrelddeel waar die reg hoofsaaklik sy eerste hoë vlugte bereik het, klink onder magtige Forum-suile die Romeinse afskeidswens ons tegemoet - Sterkte! Nie die vrede van eensame woestyn-kalmte 
sonder stryd; ook nie die sterkte van die adelaar wat swewend oor die legioene die pax Romana moet afdwing nie - 'n ander vrede, 'n ander sterkte dring ons. In die versoening met God deur die geloof in die sterwe en opstanding van ons Saligmaker, Jesus Christus, is vrede en sterkte tot sintese gebring.

Die vrede van Bo gegewe is ook in oorlogstyd ons sterkte.

Die sterkte van Bo-gebid kondig ook vir ons die vrede an. Vrede! my geloofsbroeder, is my afskeidsgroet aan $u$.

Sterkte! my wapenbroeder, is my weersienswens.

P.U. vir C.H.O.

S. Postma.

1 Stoker, H. G.: Beginsels en Metodes in die Wetenskap, bl. 16 e.v.

2 Du Toit, J. D.: Het Calvinisme en Ons Volk. Hoewel hierdie brosjure geen datum van publikasie het nie, blyk dit tog uit die inhoud dat die rede uitgespreek is kort voor Unifikasie, d.w.s. 1809 of 1910

3 Winkel, H.: De Bijbel en het recht, in 'n bylaag tot 'n rapport van 'n kommissie van die Nederlandse Gesprek Centrum, 1956.

4 Tereg wys Du Plessis, L. J.: Inleiding tot die Algemene Regsleer of Jurisprudensie bl. 3 daarop dat daar geen rede is nie „waarom ons met Holland die naam wetenskap sal ontsé aan die besondere deel, bv. die wetenskap van die Romeinse reg of die wetenskap van die strafreg, ens."

5 Op. cit., deel 1, bl. 55 e.v.

6 Infra bl. 28.

7 Baron van Haersolte, R. A. V.: in Philosophy and Christianity, bl. 305.

8 Gereformeerde Progressieve Theologie, in Koers in die Krisis, Deel 1, bl. 150.

$\theta$ Op. cit., bl. 155

10 Cf. die insiggewende referaat van Van der Merwe, D. C. S.: Christelike Teologie en Christelike Filosofie en hulle Onderlinge Verhouding in: In die Skriflig, Jaargang 2, Nommer 8, bl. 1 e.v. en veral bl. 23 e.v. Vide ook Mekkes, J. P. A.: De Wijsgerige vraag over Theologie in Bulletin S.A.V.C.W., Nr. 18, bl. 2 e.v.

11 Op. cit., bl. 241 e.v.

12 Kuyper, A.: Encyclopaedie der Heilige Godgeleerdheid, Deel II, bl. 160.

13 Spier, J. M.: Inleiding in de Wijsbegeerte der Wetsidee, bl. 100, voetnoot 23.

14 Kuyper, A.: Encyclopaedie, Deel II, bl. 112.

15 Dooyeweerd, H.: In the Twilight of Western Thought, bl. 135.

16 Duvenage, S. C. W.: Vryheid en gebondenheid in die Teologie, in: Koers, Jaargang 32, Nr. 11, bl. 563.

17 Kuyper, A.: Encyclopaedie, Deel II, bl. 168. 
18 Ibid.

19 Stoker, H. G.: Op. cit., bl. 160 en bronne daar aangehaal.

20 Dooyeweerd, H.: Inleiding tot de Encyclopaedie der Rechtswetenschap, bl. 64.

21 Onder die dekmantel van 'n ywer om die republikeinse konstitusie te herstel laat Augustus hom soos volg in sy Mommentum Ancy ranum uit "In consulatu sexto et septimo, bella ubi civilia extinxeram, per consensum universorum potitus rerum omnium rem publican ex mea potestate in senatus populique Romani arbitrium transtuli". Cf. Kunkel, W.: An introduction to Roman Legal and Constitutional History, bl. 47. Die oorspronklike Duitse uitgawe dra die titel: „Römische Rechtsgeschichte".

22 Sy volledige titel was „imperator Romanorum gubernans imperium, qui et per misericordiam. Dei rex Francorum et Longobardorum" Hahlo, H. R. \& Kahn, E.: The South African Legal System and its background, bl. 362.

23 Brissaud, J.: A History of French Public Law, in Continental Legal History Series. Vol. IX, bl. 63.

24 In Revue de theologie et des questions religieuses.

25 Waterink, J.: "Rousseau en het Calvinisme" in Wetenschappelijke Bijdragen, bl. 14.

26 Aangehaal in Kuyper, A.: Het Calvinisme, bl. 67.

27 Mathey, J. L.: The rise of the Dutch Republic. A history, Vol II, bl. 489 .

28 Idem, bl. 568

29 Nederl. Geloofsbelydenis Art. XXXVI.

30 Cf. Bohatec, J.: Calvin und das Recht, bl. 133 e.v.

31 Kuyper, A.: Het Calvinisme, bl. 86.

32 In sy populer-wetenskaplike werk De Maatschappij der Toekomst.

33 Cf. Popma, K. J.: Nadenken over de Tijd

34 Encyclopaedie der Heilige Godgeleerdheid, Deel II, bl. 156

35 Handelinge 25 : 12.

36 Responsa Papiniani, V, ad legem 17.

37 Winkel, H.: Op. cit., bl. 42

38 Vide die analise en kommentaar van Van der Keessel, D. G.: Praelectiones iuris hodierni ad Hugoris Grotii introductionem ad lurisprudention Hollandicam (uitgawe besorg deur Van Warmelo e.a.), 1.4.2. op Tacitus, Op. cit., 24 en 25.

39 De Bleccourt, A. S. en Fischer, H. F. W. D.: Kort begrip van het Oud-Vaderlandse Burgerlijk Recht, 6e ultgawe, bl. 108

40 Geesink, W.: Van 's Heeren Ordinantiën, Deel II, band II, bl. 46.

41 Op. cit., 1, 3, 5.

42 Idem, 1, 3, 4. Die Latynse teks lui: „Pro natis homínibus habentur tantum, qui corpus habent ad recipiendam mentem rationalem idoneum et capax. Quae definitio Grotii clare indicat etiam ostenta et portenta, quae quid habent praeternaturale $L .38 \mathrm{D}$. de V. S. pro hominibus habenda esse argumento L. 102 D. de aedil. Ed."

43 Von Liszt, F.: Totung und Lebensgefahrdung, in Vergleichende Darstellung des Deutschen und Ausländischen Strafrechts, Algemeiner 
Teil, Band V, bl. 133. (Hierdie reeks word gewoonlik afgekort tot V.D.A.T.).

44 Aangehaal in Stooss, C.: Grundzuge der Schweizer. Strafrecht in Auftrage des Bundesrates vergleichend dargestellt, II, p. 15

45 den Hartogh, G. M.: in Christelijke Encyclopaedie, Band IV, s.v. Recht, bl. 687.

46 Langemeijer, G. E.: Unterschiede und Zusammenhänge bei Recht, Gerechtigkeit und Sittlichkeit in Philosophy and Christianity, bl. 237. Hierdie aangepaste aanhaling ontleen Langemeijer egter aan Van Kan: Inleiding tot de Rechtswetenschap.

47 Van Hamel, G. A.: Inleiding tot de studie van het Nederlandse Strafrecht, $4 \mathrm{e}$ druk, bl. 65.

48 Jousse, Traité de la justice criminelle, préface, bl. 64

49 Vargha, J.: Die Abschaffung der Strafknecht-schafft, II, bl. 241

50 Reiwald: Die Gesellschaft und ihre Verbrecher, bl. 307.

51 Swanepoel, H. L.: Strafregteorieë, in Bulletin van die S.A.V.C.W., Jaargang 1, Nr. 3, b. 103. Cf. Van Bremmelen, J. M. en Van Hattum, W. F. C.: Hand- en Leerboek van het Nederlandse Strafrecht, Deel I, bl. 25.

52 Schepper: Strafrecht en Wereldbeschouwing, bl. 29.

53 Van Bemmelen en Van Hattum: Op. cit., bl. 38 met 'n beroep in die aangehaalde gedeelte op Kisch, 1, Vrije wil, determinisme en strafrecht, Tijdschrift voor Strafrecht, 58 (1949), bl. 236.

54 Kuyper, A.: Het Calvinisme, bl. 101

55 Kuyper, A.: De Gemeene Gratie, I, bl. 71-72.

56 Idem, bl. 73.

57 Rees, J. R.: Mental variations and criminal behaviour, in English Studies in Criminal Science, 1944, bl. 7.

58 Chevallier, G.: Clochemerle, bl. 199. 